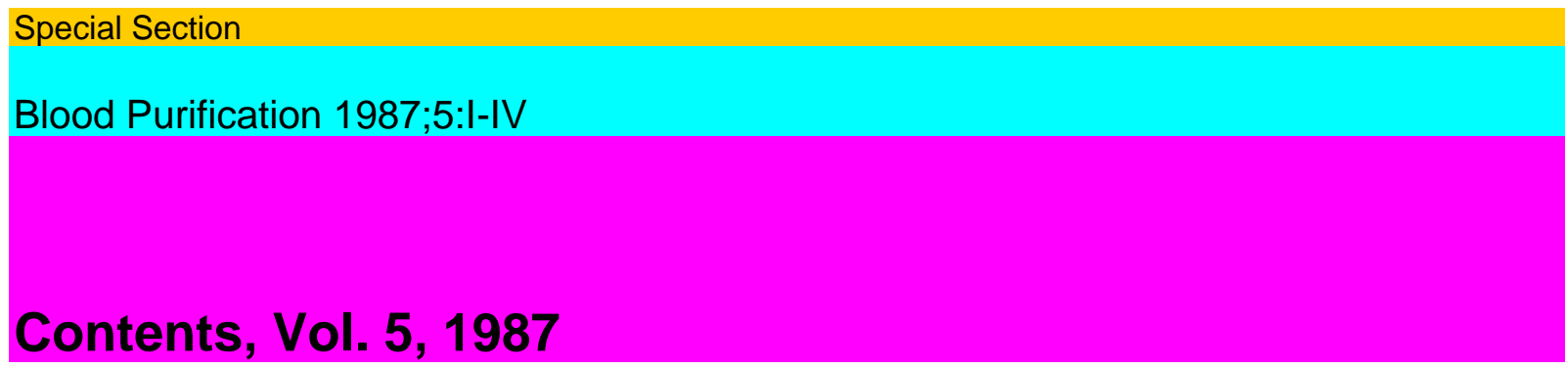

\title{
No. 1 Editorial
}

Hemodialysis or Hemofiltration - the Patient's View

Hüfler, M.; Asmus, G.; Herrath, D. von; Schaefer, K

Expert Review

Choosing a Treatment Modality for the Infant, Child and Adolescent with Endstage Renal

Disease

Fine, R.N 4

Original Paper

A Novel Bioassay to Predict the Clinical Response to Cryofiltration Treatment.

A Preliminary Report

Jørstad, S.; Henderson, L.W.; Frigon, R.P.; Curd, J.; Ward, D

The Ability of Uremic Serum to Induce Neutrophil Chemotaxis in Relation to Hemo dialysis

Pedersen, J.O.; Knudsen, F.; Nielsen, A.H.; Grunnet, N 24

Defective Protein C in Uraemia

Sørensen, P.J.; Nielsen, A.H.; Knudsen, F.; Dyerberg, J 29

Arteriovenous Hemodiafiltration Associated with Continuous Arteriovenous Hemofiltra tion: A Combined Therapy for Acute Renal Failure in the Hypercatabolic Patient

Ronco, C; Brendolan, A.; Bragantini, L.; Chiaramonte, S.; Fabris, A.; Feriani, M.;

Dell'Aquila, R.; Milan, M.; La Greca, G 33

Cardiovascular Function and Alveolar Gas Exchange during Isovolemic Hemodialysis with

Acetate in Healthy Man

Danielsson, A.; Freyschuss, U.; Bergström, J 41

AIDS and Apheresis Procedures - Therapeutic and Safety Considerations

Kiprov, D.D.; Simpson, D.M.; Pfaeffl, W.; Romanick-Schmiedl, S.; Abrams, D.;

Miller, R.G 51

Announcement 56

No. 2-3 Blood-Membrane Interaction in Extracorporeal Circuits

Biocompatibility of Artificial Organs: An Overview

Henderson, L.W.; Chenoweth, D 100

First-Use Syndrome in Patients Treated with Hollow-Fiber Dialyzers

Villarroel, F 112

The Possible Role of $\mathrm{L} / \mathrm{mM} / \mathrm{i} \dot{\mathrm{c}}$-Amebocyte-Lysate-Reactive Material in Hemodialysis.

First-Use Syndrome

Pearson, F.C 115

Biocompatibility of Different Hemodialysis and Plasmapheresis Membranes

Jørstad, S $\quad \therefore .123$

Analysis of Density Changes and Chemotactic Receptors of Leukocytes from Chronic

Hemodialysis and Peritoneal Dialysis Patients 
Lewis, S.L.; Van Epps, D.E.; Chenoweth, D.E 138

IV Contents

Animal Models to Study the Cardiopulmonary Effects of Artificial Kidney Membranes Cheung, A.K 155

Assessment of Complement Activation during Extra corporeal Circulation by Measure ment of Complement Split C3d

Knudsen, F 162

Cardiopulmonary Bypass: Studies on Its Damaging Effects

Kirklin, J.K.; Blackstone, E.H.; Kirklin, J.W 168

Ex vivo and in vivo Protein A Perfusion: Background, Basic Investigations, and First

Clinical Experiences

Samtleben, W.; Schmidt, B.; Gurland, H.J 179

Announcement

192

No. 4 Editorial

Short-Term Dialysis - Long-Term Complications. Ten Years Experience with ShortDuration Renal Replacement Therapy

Wizemann, V.; Kramer, W 193

In-Depth Review

Analysis of Membrane Processes for Blood Purification

Colton, C.K 202

Original Paper

Treatment of Cirrhotic Ascites by Dialytic Ultrafiltration with a Hemofilter System

Lai, K.N.; Leung, J.W.C.; Swaminathan, R.; Panesar, N.S 252

Hemofilter Reuse in Maintenance Hemofiltration

Lai, K.N.; Mac-Moune Lai, F.; Leung, A.C.T.; Swaminathan, R 256

Enhanced Biocompatibility with a New Cellulosic Membrane: Cuprophan ${ }^{\circledR}$ versus

Hemophan ${ }^{\circledR}$

Schaefer, R.M.; Hörl, W.H.; Kokot, K.; Heidland, A262

Abstracts

5th Annual Meeting of the International Society of Blood Purification . June 22-24, 1987,

Stockholm 268

Author Index 320

Subject Index 324 